\title{
nature
}

\section{National vandalism at the US Geological Survey}

An ill-considered library cut proposed last week would devastate an irreplaceable resource for the Earth sciences and for related industries, and should be vigorously opposed.

T imes are hard at the United States Geological Survey (USGS). Two years ago, it escaped being abolished as part of the Republicans' anti-federalist and supposedly budget-balancing "Contract with America", only to come under renewed threat a few months later from a proposal - again from the Congress, and still pending that all of the Department of the Interior's surveying and mapping activities should be handed over to the private sector.

But if the survey's mood is uncertain, its Geologic Division has had more immediate problems to face. With more research scientists than any of the other divisions, it has found it harder to justify all of its programmes as directly relevant to national needs. A forced staff reduction of 20 per cent in October 1995 has left its mark on division morale.

Even against this background, the recent decision to decrease the USGS library's acquisitions budget by almost 50 per cent (see page 637 ), and to give staff only one week to express views as to which subscriptions should be retained, stands out as cruel and unusual punishment. By common consensus, the library's journal holdings have already been pared to the bone over the past decade: duplicate subscriptions and titles readily available from other sources have long since disappeared. A cut of the magnitude envisaged would seriously jeopardize the quality of scholarship at the USGS, and thereby the quality of information that the survey can provide to the government.

By all accounts, the decision is more the result of conflicts between the survey's divisions than of strategic logic: the library sits within the Geologic Division, where most of the research is done, but the other divisions are charged according to their usage. At least one of the other divisions is said to have kicked up a fuss this year about the everincreasing cost, and the result was the dramatic cut.

The repercussions, however, have been anything but parochial, and seem to have taken the survey administrators by surprise. For it turns out that they have been sitting on nothing less than a national treasure - in the appropriate words of one former survey employee, a "master repository of the world's geoscience literature". University librarians throughout the country know the USGS library as the place where they can find material that cannot be found anywhere else. And librarians are not the only ones in the know. For example, after the collapse of the Soviet Union, a team of Exxon researchers were able to spend two productive weeks in the survey's library, assessing the geology of formerly inaccessible regions that had suddenly become attractive possibilities for exploration.

Viewed in this light, what seemed at first to be merely an inept management decision - inadequate in consultation and with insufficient appreciation of its significance - takes on the appearance of a national scandal. A resource that is not merely used but depended on by academic institutions, industry, regional agencies and the general public should not be at the mercy of an administrator trying to run one division of a troubled agency. People from outside the USGS account for almost half of the use made of the library, yet about 98 per cent of the library's funding comes from the survey's missionoriented divisions, which have their own interests to promote. It comes as no surprise that such a mismatch has not been able to bear the strain of prolonged level funding or worse.

It is clear that the USGS library is, in all but name, a national library - akin to the Library of Congress and the national libraries of medicine, agriculture and education. Whether it likes it or not, the USGS is responsible for the future of this national resource. It should first remove the library from the Geologic Division, and acknowledge that maintaining a world-class Earth sciences library is part of the survey's overall mission of providing "Earth science in the public service". It should then ask the Congress to establish the USGS library as the National Library of Geoscience, funded explicitly as a line item in the budget. In this way, its wider role would be enshrined and, it is to be hoped, preserved from further attrition.

\section{More freedom in the Framework}

\section{The European Commission should have more independence in its research programme management.}

$\longrightarrow$ esearchers familiar with the long delays in obtaining grants from the European Commission may not realize that one obstacle lies in the conflicting interests of the European Union's member states. In its newly proposed fifth Framework research programme (see page 639), the commission is asking for freedom to execute programmes without the constant supervision of political authorities. It suggests that its programme committees, which comprise national experts, should no longer "help" with the implementation of individual programmes, but should act only in an advisory capacity. This, it argues, will make decision-making smoother and quicker, and thus get money to researchers faster. And it has the support of the recent independent report by Viscount Davignon and colleagues on the running of past Framework programmes.
Member states are reacting aggressively to the idea, appearing not to trust the commission to deliver satisfactory results. But the interests of researchers have to be considered seriously, and vague distrust is not a sufficient reason to discard the idea out of hand. The burden of proof lies with the member states to justify their concerns.

The commission, too, has a burden of proof. Its proposal is too vague about its plans for a management structure that will need to be radically different to handle the complex matrix system it envisages for the fifth Framework. That is a justified source of concern for member states and for the European Parliament. All involved in the forthcoming decision process need to ensure that member states and the commission clarify their positions, in the interests of the effectiveness of researchers on whom they ultimately depend. 